\title{
Biodiversity of City Dumpsites: What Future for the Environment?
}

\author{
Oka Peter Onen ${ }^{1} *$; Bassey John Bassey ${ }^{1}$ \\ ${ }^{l}$ Department of Geography and Environmental Science, University of Calabar, Nigeria.
}

\begin{abstract}
The value and volume of dumpsites in growing population attracts biodiversity, with little interest on its impact on the future of the society. This study ascertained the animal communities along dumpsites in Calabar Metropolis, assessed the interaction between community members and highlighted the environmental implication. Participatory Appraisal (PA), Focal Species Approach (FSA) and field observations enhanced the collection of inventories for the study. Forty animal species formed the baseline data on three dumpsites among the three major ethnic settlements in the Metropolis. Analysis of Variance (ANOVA) was used to compare animal composition among the dumpsites and PA to estimate the health impact sphere. Forty per cent of animal species identified are residents, 37.5 per cent local migrants and 22.5 per cent wanderers. Further, 42.5 per cent of the animal community used the dumpsites throughout the 12 months of the year with the highest number of species occurring during rainy season. Result showed that the Table F-value, 3.23, is less than the calculated Fvalue, 336.13 , at 0.05 . This implied that there is a significant difference in animal composition diversity in the dumpsites in Calabar Metropolis. Hence, this confirmed that the animal diversity along dumpsites was determined by content rather than extent or location. This study has confirmed the importance of understanding the management of the interacting assemblages of biodiversity at city dumpsites and the threat to human health created. Hence, the role of animal community along dumpsites in propagating, proliferating and infesting humans, need continuous attention.
\end{abstract}

Keywords: Biodiversity, Dumpsites, Health impact sphere, Calabar Metropolis.

\section{INTRODUCTION}

The rainforest accounts for approximately six per cent of the landscape where rainfall is in excess of $2000 \mathrm{~mm}$ per year. In a single acre of rainforest, it has been observe that in Panama rainforest, there are as many as 40 million animals apart from bacteria, fungi and mould [1]. City dumpsite, an artificial ecosystem, is of considerable value to biodiversity. The rapid growth experienced in urban centers worldwide is fast leading to change in morphological pattern resulting in demand for natural resources. This has given rise to the volume of garbage generated within urban population. There is now a growing need to evaluate the impact of dumpsites management on biodiversity in order to maintain and enhance the value of wildlife value at the artificial ecosystem. The understanding of the relationship between biodiversity and city dumpsites will enable wildlife managers to make informal choices to provide sustainable environment for the future. A study that highlighted the contribution of city dumpsites to biodiversity conservation, sampled nine (9) dumpsites in Cross River State, Nigeria, brought to focus the unnoticed benefits of city dumpsites [2].

The value of garbage developed among city dwellers varies among individuals, families, private and public institutions. This incidence has resulted in pollution, alteration and loss of biodiversity. Similar studies suggest that sustainable human-induced environmental changes link to urban growth on regional scale and could become an important factor in biodiversity conservation [3], [4] and [5]. About 20 per cent of the world's population lives in biodiversity hotspot region, hence creating an interjection between biodiversity and urbanization[6]. On this premise that other scholars, concluded that predicting patterns of urbanization in the areas of high biodiversity are critical for conservation [7].

Studies that focus on the realities of the growth of dumpsites and its impact on biodiversity in developing countries is still few particularly in West African sub-region. The importance of species diversity is significant for the economic management, particularly in agriculture and tourism. Studies have been made on megacities not located in biodiversity rich areas at the expense of pristine settlements located in biodiversity rich areas that are of serious concern to conservation. As Calabar is a pristine settlement, this has entrenched the choice of the Metropolis for the research on biodiversity of artificial ecosystem relationship, with focus on faunal community. Less is known of the faunal than of the floral composition of the city dumpsites in Calabar.

Calabar Metropolis lies within Latitude $4^{\circ} 57^{\prime} \mathrm{N}$ and $5^{\circ} 5^{\prime} \mathrm{N}$ and Longitude $8^{\circ} 19^{\prime} \mathrm{E}$ and $8^{\circ} 26^{\prime} \mathrm{E}$. The metropolis is actually a fusion of Calabar Municipality and Calabar South Local Government Area and is sited 
on the premonitory etched and washed by the Great Kwa and Calabar rivers, the Creeks of Cross River (Fig. 1). The city is fast becoming ecological sensitive zone in view of its neighbourhood to these water bodies. It has a temperature range, $25^{\circ}-28^{\circ} \mathrm{C}$, which remains relatively constant throughout the year with little variation between daytime and nighttime temperatures. The annual rainfall is a little above $3,000 \mathrm{~mm}$ andmean monthly rainfall ranging between 38 and $455 \mathrm{~mm}$ with a double maxima yearly. The mean relative humidity is between $82-92$ per cent.

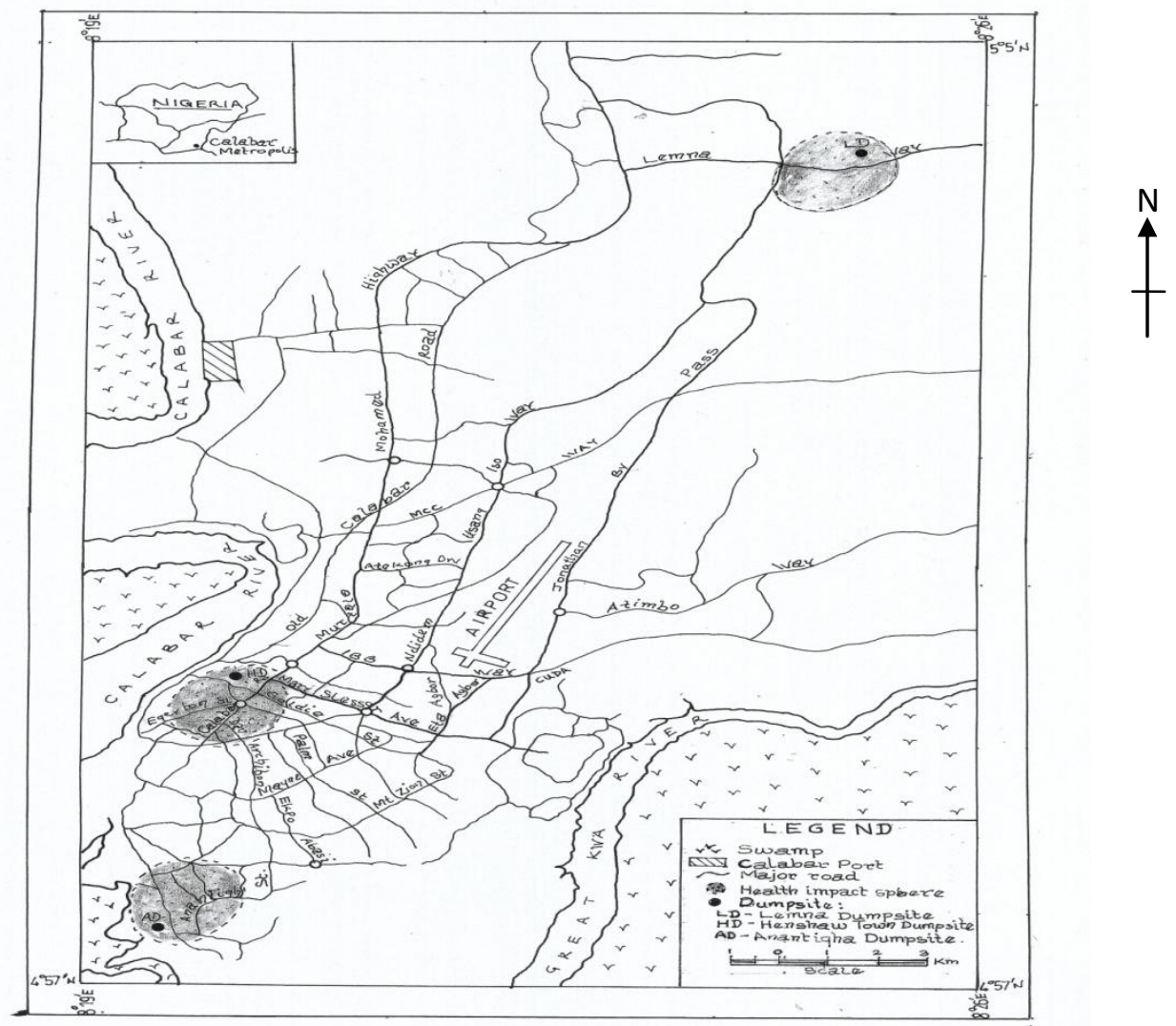

SOURCE: Author's Fieldwork in collaboration with Cartography Unit, Department of Geography and Environmental Science, University of Calabar, Nigeria.

Fig 1: Dumpsites location and potential health impact sphere in Calabar Metropolis.

Calabar Metropolis has a landmass of $406 \mathrm{~km}^{2}$ with an average elevation of 32 meters above sea level. The 2006 national population report showed that the population of the metropolis was 371,022. At a projection rate of 0.89 per cent, it rises to 466,800 and 470,950 in 2015 and 2016 respectively [8]. The population density currently is approximately 910 per square kilometer. The growth experienced in urban population has enhanced the volume of waste generated within the metropolis. The waste comprises of packaging materials, plastic bags, paper, clothes, toys and electrical materials. The bulk of the wastes are leftover food, vegetable waste and motor spare parts. Calabar Urban Development Authority (CUDA) and the Cross River State Ministry of Environment are responsible for installing of waste bins and the collection of garbage at designated points. Proper method of waste disposal and its management is a matter of importance to maintain clean society. The quality of life among the neighbourhood of city dumpsites is similar to the poor in rural areas. Families work long hours, income is uncertain and most cases difficult trade-offs made between expenditures on nutrition, medical care and education. Currently the metropolis is facing the problem of waste management; garbage evacuation is slow and the decaying stuff produce unpleasant pious liquid. Domestic waste collected in low quality and open vans fall off along roadsides. The accumulated waste at collection points and litters along the roads, apart from existing as agents of health hazard, attract other organisms [9], [10]. The animal community of city dumpsites are poorly recorded and understood in Calabar Metropolis as it is in most cities of undeveloped and developing countries. This research aimed at ascertaining the animal community in city dumpsite and its environmental implications. 
II.

OBJECTIVES

The objectives of the research is to:

1. Ascertain the animal community along the dumpsites of the study area,

2. Assess the interaction between community members, and

3. Examine the environmental health implications of animal community along the dumpsites.

\section{SIGNIFICANCE AND SCOPE}

This work provides a better insight and understanding of the faunal composition along dumpsites; further brings to limelight the propagation, proliferation or spread of infectious diseases potentials created by animal community in the environment. A greater proportion of all human illnesses are of infectious type because of invasion of pathogens; viruses, bacteria fungi and other microorganisms, and their multiplication in the body, sometimes resulting in epidemics. Certainly with high rainfall, temperature and relative humidity throughout the year in Calabar, the dumpsites have become mini-zones of intensive biological activity and hence the source of many disease-transmitting organisms. Health authorities would find this work quit illuminating and useful in planning and managing dumpsites in the city regarding the control and prevention of infectious disease propagation and spread. The scope of the study was limited to animal in the wild and stray animals seen at dumpsites. Birds using the air space did not form the integral part of the inventory but animals sighted by the neighbourhood within the month of observation were included.

\section{METHODOLOGY}

This study adopted suitable methodologies comprising among others literature review, field observation and identification of species. The participatory appraisal (PA) enhanced the collection of inventory on fauna among individuals interviewed. Focal species approach (FSA) was used to compile a list of species for this study: species that are representatives of the wider element of the dumpsite animal community and key ecological processes. Empirical observations were used to identify the animal communities of the dumpsites and Analysis of variance (ANOVA) for analyzing the data. The difference in mean value was of significance level, 0.05 . This relates to the characteristics and requirements of a variety of ecological representative of focal species. It has therefore been ascertained that such approach has received attention of scholars, being easy to understand and readily applicable to management problems [11]. Fortyanimal species served as the baseline data for this study. One major dumpsite was chosen from each of the three major ethnic settlements in Calabar Metropolis: Henshaw Town dumpsite (Efik), Anantigha dumpsite (Efut) and Lemna dumpsite (Qua) (Fig. 1); hence, three dumpsites strategically located in the metropolis were used. The research lasted for the 12 months of the year 2016. Participatory Appraisal at the neighbourhood was used to estimate the health impact sphere of the dumpsites.

\section{RESULT AND DISCUSSION}

Three statuses of animal species used the dumpsites, namely resident local migrants and wanderers. Resident species refers to animal species that remain within a definable home range throughout the year, local migrants move short distances between breeding and non breeding (dumpsites) places and wanderers status make unpredictable movements in response to rain or high temperatures, hence inhabit drier or wet areas respectively(TABLE 1). The resident species represent forty per cent, local migrants 37.5 per cent and species with wanderer's status 22.5 per cent. Result further show that 35 per cent of the animal community represent arthropods, 32.5 percent birds, 10 per cent mammals while reptelia and molusca recorded 7.5 per cent representations each. Amphibian and annelid trailed behind with 5.0 and 2.5 per cent representations each.

In addition, 42.5 per cent representing 18 animal communities used the dumpsites throughout the 12 months of the year. Among the mammals are Canis familiaris, Felis catus and Ratus ratus; aves include Columbia livia, Cathartes aura, Gallus gallus domesticus, Pica pica and Bulbulcus ibis. The highest number was recorded among the arthropods: Camponotus spp, Lascus niger, Heteropoda spp, Musa domestica, Periplaneta americana, Trigoniulus corallines, Bombus impatiens and Apis mellifera representing 20 per cent of the animal community in the dumpsites. Caloles versicolor and Lumbricus terrestris from reptelia and annelid respectively recorded 2.5 per cent representations each.

The highest representation of animal community occurred during the rainy season.Gypohierax angolensis, Nija nigricollis and Opheodrys vernalis were rare. Anopheles stephensi, Aedes aegyptis and Anisoptera spp were moderately dominant and observed in both dry and rainy seasons. City dumpsites are breeding sites for Camponotus spp, Lasius niger, Anopheles stephensi, Aedes aegyptis, Telescopium sp and Lumbricus terrestris.Cricetomys gambianus, Ratus ratus, Caloles versicolor, Bufo bufo and Rana tigrina are primary consumers. Bulbulcus ibis, Pica pica and Cathartes aura (secondary consumers) feed on the primary consumers and food waste at the dumpsites. The tertiary consumers such as Felis catus, Canis familiaris and Milvus migrans feed on the secondary consumers. Pica pica and Cathartes aura are the most common raptor 
and scavengers in the study area. Cricetomys gambianus is predominantly nocturnal, active at late afternoon early morning and occasionally in a calm mid-day. The relationship that exists among dumpsite locations, primary and secondary consumers, and tertiary consumers create an energy flow that is unique with ecological systems. Dumpsites in the study area serve as habitat for Cricetomys gambianus that the indigenous people call it 'Okon Calabar' [2]. This species of mammal in under threat; a comparison of sites show that Cricetomys gambianus persist in sites with stock of food waste but declined at sites without food waste and high pressure of predators.

TABLE 1: Animal Distribution At The Dumpsites In Calabar Metropolis

\begin{tabular}{|c|c|c|c|c|c|c|c|c|c|c|c|c|c|c|c|c|c|}
\hline $\mathbf{S} / \mathbf{N}$ & Species & $\begin{array}{l}\text { Common } \\
\text { Name } \\
\end{array}$ & Class & Status & $\mathbf{J}$ & $\mathbf{F}$ & $M$ & $\mathrm{~A}$ & $M$ & $\mathbf{J}$ & $\mathbf{J}$ & A & $\mathbf{S}$ & 0 & $\mathbf{N}$ & D & Total \\
\hline 1 & Aedes aegyptis & Mosquito & Arthropoda & $\mathrm{R}$ & & $\mathrm{x}$ & $\mathrm{x}$ & & & $\mathrm{x}$ & $\mathrm{x}$ & $\mathrm{x}$ & $\mathrm{x}$ & $\mathrm{x}$ & $\mathrm{x}$ & $\mathrm{x}$ & 9 \\
\hline 2 & $\begin{array}{l}\text { Anopheles } \\
\text { stephensi }\end{array}$ & Mosquito & Arthropoda & $\mathrm{R}$ & & & & & & $\mathrm{x}$ & $\mathrm{x}$ & $\mathrm{x}$ & $\mathrm{x}$ & $\mathrm{x}$ & $\mathrm{x}$ & $\mathrm{x}$ & 7 \\
\hline 3 & Aisoptera sp & Dragonfly & Arthropoda & $\mathrm{R}$ & $\mathrm{x}$ & $\mathrm{x}$ & $\mathrm{x}$ & & & $\mathrm{x}$ & $\mathrm{x}$ & $\mathrm{x}$ & $\mathrm{x}$ & $\mathrm{x}$ & $\mathrm{x}$ & $\mathrm{x}$ & 10 \\
\hline 4 & Apis mellifera & Honey Bee & Arthropoda & $\mathrm{M}$ & $\mathrm{x}$ & $\mathrm{x}$ & $\mathrm{x}$ & $\mathrm{x}$ & $\mathrm{x}$ & $\mathrm{x}$ & $\mathrm{x}$ & $\mathrm{x}$ & $\mathrm{x}$ & $\mathrm{x}$ & $\mathrm{x}$ & $\mathrm{x}$ & 12 \\
\hline 5 & $\begin{array}{l}\text { Bombus } \\
\text { impatiens }\end{array}$ & $\begin{array}{l}\text { Bumble } \\
\text { Bee }\end{array}$ & Arthropoda & $\mathrm{M}$ & $\mathrm{x}$ & $\mathrm{x}$ & $\mathrm{x}$ & $\mathrm{x}$ & $\mathrm{x}$ & $\mathrm{x}$ & $\mathrm{x}$ & $\mathrm{x}$ & $\mathrm{x}$ & $\mathrm{x}$ & $\mathrm{x}$ & $\mathrm{x}$ & 12 \\
\hline 6 & Bufo bufo & Toad & Amphibian & M & & & & & $\mathrm{x}$ & $\mathrm{x}$ & $\mathrm{x}$ & $\mathrm{x}$ & $\mathrm{x}$ & $\mathrm{x}$ & & & 6 \\
\hline 7 & Bulbulcus ibis & Cattle Egret & Ave & $\mathrm{W}$ & $\mathrm{x}$ & $\mathrm{x}$ & $\mathrm{x}$ & $\mathrm{x}$ & $\mathrm{x}$ & $\mathrm{x}$ & $\mathrm{x}$ & $\mathrm{x}$ & $\mathrm{x}$ & $\mathrm{x}$ & $\mathrm{x}$ & $\mathrm{x}$ & 12 \\
\hline 8 & Camponotus sp. & Black Ant & Arthropoda & $\mathrm{R}$ & $\mathrm{x}$ & $\mathrm{x}$ & $\mathrm{x}$ & $\mathrm{x}$ & $\mathrm{x}$ & $\mathrm{x}$ & $\mathrm{x}$ & $\mathrm{x}$ & $\mathrm{x}$ & $\mathrm{x}$ & $\mathrm{x}$ & $\mathrm{x}$ & 12 \\
\hline 9 & Canis familiaris & Dog & Mammal & $\mathrm{M}$ & $\mathrm{x}$ & $\mathrm{x}$ & $\mathrm{x}$ & $\mathrm{x}$ & $\mathrm{x}$ & $\mathrm{x}$ & $\mathrm{x}$ & $\mathrm{x}$ & $\mathrm{x}$ & $\mathrm{x}$ & $\mathrm{x}$ & $\mathrm{x}$ & 12 \\
\hline 10 & $\begin{array}{l}\text { Cochlicopa } \\
\text { lubrica }\end{array}$ & Moss Snail & Molusca & $\mathrm{R}$ & & & & $\mathrm{x}$ & $\mathrm{x}$ & $\mathrm{x}$ & $\mathrm{x}$ & $\mathrm{x}$ & $\mathrm{x}$ & & & & 5 \\
\hline 11 & Columbia livia & Pigeon & Ave & M & $\mathrm{x}$ & $\mathrm{x}$ & $\mathrm{x}$ & $\mathrm{x}$ & $\mathrm{x}$ & $\mathrm{x}$ & $\mathrm{x}$ & $\mathrm{x}$ & $\mathrm{x}$ & $\mathrm{x}$ & $\mathrm{x}$ & $\mathrm{x}$ & 12 \\
\hline 12 & $\begin{array}{l}\text { Caloles } \\
\text { versicolor }\end{array}$ & Lizard & Reptelia & $\mathrm{W}$ & $\mathrm{x}$ & $\mathrm{x}$ & $\mathrm{x}$ & $\mathrm{x}$ & $\mathrm{x}$ & $\mathrm{x}$ & $\mathrm{x}$ & $\mathrm{x}$ & $\mathrm{x}$ & $\mathrm{x}$ & $\mathrm{x}$ & $\mathrm{x}$ & 12 \\
\hline 13 & Coleoptera sp. & Beetle & arthropoda & $\mathrm{R}$ & & & & $\mathrm{x}$ & $\mathrm{x}$ & $\mathrm{x}$ & $\mathrm{x}$ & $\mathrm{x}$ & $\mathrm{x}$ & & & & 6 \\
\hline 14 & Cathartes aura & Vulture & Ave & M & $\mathrm{x}$ & $\mathrm{x}$ & $\mathrm{x}$ & $\mathrm{x}$ & $\mathrm{x}$ & $\mathrm{x}$ & $\mathrm{x}$ & $\mathrm{x}$ & $\mathrm{x}$ & $\mathrm{x}$ & $\mathrm{x}$ & $\mathrm{x}$ & 12 \\
\hline 15 & $\begin{array}{l}\text { Cricetomys } \\
\text { gambianus }\end{array}$ & Giant Rat & Mammal & $\mathrm{R}$ & $\mathrm{x}$ & & $\mathrm{x}$ & & $\mathrm{x}$ & & & $\mathrm{x}$ & & & & & 4 \\
\hline 16 & Felis catus & Cat & Mammal & $\mathrm{M}$ & $\mathrm{x}$ & $\mathrm{x}$ & $\mathrm{x}$ & $\mathrm{x}$ & $\mathrm{x}$ & $\mathrm{x}$ & $\mathrm{x}$ & $\mathrm{x}$ & $\mathrm{x}$ & $\mathrm{x}$ & $\mathrm{x}$ & $\mathrm{x}$ & 12 \\
\hline 17 & $\begin{array}{l}\text { Gypohierax } \\
\text { angolensis }\end{array}$ & $\begin{array}{l}\text { Palm-nut } \\
\text { Vulture }\end{array}$ & Ave & W & & & $\mathrm{x}$ & & & & & & & & & & 1 \\
\hline 18 & $\begin{array}{l}\text { Galus galus } \\
\text { domesticus }\end{array}$ & $\begin{array}{l}\text { Domestic } \\
\text { Hen }\end{array}$ & Ave & M & $\mathrm{x}$ & $\mathrm{x}$ & $\mathrm{x}$ & $\mathrm{x}$ & $\mathrm{x}$ & $\mathrm{x}$ & $\mathrm{x}$ & $\mathrm{x}$ & $\mathrm{x}$ & $\mathrm{x}$ & $\mathrm{x}$ & $\mathrm{x}$ & 12 \\
\hline 19 & Heteropoda sp. & Spider & Arthropoda & $\mathrm{R}$ & $\mathrm{x}$ & $\mathrm{x}$ & $\mathrm{x}$ & $\mathrm{x}$ & $\mathrm{x}$ & $\mathrm{x}$ & $\mathrm{x}$ & $\mathrm{x}$ & $\mathrm{x}$ & $\mathrm{x}$ & $\mathrm{x}$ & $\mathrm{x}$ & 12 \\
\hline 20 & $\begin{array}{l}\text { Halcyon } \\
\text { malimbica }\end{array}$ & $\begin{array}{l}\text { Blue- } \\
\text { breasted } \\
\text { kingfisher }\end{array}$ & Ave & $\mathrm{M}$ & & & & & $\mathrm{x}$ & $\mathrm{x}$ & $\mathrm{x}$ & $\mathrm{x}$ & $\mathrm{x}$ & $\mathrm{x}$ & $\mathrm{x}$ & & 7 \\
\hline 21 & Helix aspersa & $\begin{array}{l}\text { Garden } \\
\text { Snail }\end{array}$ & Molusca & $\mathrm{W}$ & & & & $\mathrm{x}$ & $\mathrm{x}$ & $\mathrm{x}$ & $\mathrm{x}$ & & & & & & 4 \\
\hline 22 & Lasius niger & Black Ant & Arthropoda & $\mathrm{R}$ & $\mathrm{x}$ & $\mathrm{x}$ & $\mathrm{x}$ & $\mathrm{x}$ & $\mathrm{x}$ & $\mathrm{x}$ & $\mathrm{x}$ & $\mathrm{x}$ & $\mathrm{x}$ & $\mathrm{x}$ & $\mathrm{x}$ & $\mathrm{x}$ & 12 \\
\hline 23 & $\begin{array}{l}\text { Lumbricus } \\
\text { terrestris }\end{array}$ & Earthworm & Annelida & $\mathrm{R}$ & $\mathrm{x}$ & $\mathrm{x}$ & $\mathrm{x}$ & $\mathrm{x}$ & $\mathrm{x}$ & $\mathrm{x}$ & $\mathrm{x}$ & $\mathrm{x}$ & $\mathrm{x}$ & $\mathrm{x}$ & $\mathrm{x}$ & $\mathrm{x}$ & 12 \\
\hline 24 & $\begin{array}{l}\text { Lithobius } \\
\text { forficatus }\end{array}$ & Centipede & Arthropoda & $\mathrm{R}$ & & & & & & $\mathrm{x}$ & $\mathrm{x}$ & $\mathrm{x}$ & $\mathrm{x}$ & $\mathrm{x}$ & $\mathrm{x}$ & $\mathrm{x}$ & 7 \\
\hline 25 & Milvus migrans & Black Kite & Ave & $\mathrm{W}$ & $\mathrm{x}$ & $\mathrm{x}$ & $\mathrm{x}$ & $\mathrm{x}$ & & & & & & $\mathrm{x}$ & $\mathrm{x}$ & $\mathrm{x}$ & 7 \\
\hline 26 & Musa domestica & Housefly & Arthropoda & $\mathrm{R}$ & $\mathrm{x}$ & $\mathrm{x}$ & $\mathrm{x}$ & $\mathrm{x}$ & $\mathrm{x}$ & $\mathrm{x}$ & $\mathrm{x}$ & $\mathrm{x}$ & $\mathrm{x}$ & $\mathrm{x}$ & $\mathrm{x}$ & $\mathrm{x}$ & 12 \\
\hline 27 & Nija nigricollis & $\begin{array}{l}\text { Black- } \\
\text { necked } \\
\text { Spitting } \\
\text { cobra }\end{array}$ & Reptelia & $\mathrm{R}$ & & & & $\mathrm{x}$ & & & & & & $\mathrm{x}$ & & & 2 \\
\hline 28 & $\begin{array}{l}\text { Opheodrys } \\
\text { vernalis }\end{array}$ & $\begin{array}{l}\text { Smooth } \\
\text { Green } \\
\text { Snake }\end{array}$ & Reptelia & $\mathrm{M}$ & & & & & & $\mathrm{x}$ & $\mathrm{x}$ & $\mathrm{x}$ & & & & & 3 \\
\hline 29 & Hirundo rustica & $\begin{array}{l}\text { Barn } \\
\text { Swallow }\end{array}$ & Ave & $\mathrm{M}$ & & & & & $\mathrm{x}$ & $\mathrm{x}$ & $\mathrm{x}$ & $\mathrm{x}$ & $\mathrm{x}$ & & & & 5 \\
\hline
\end{tabular}




\begin{tabular}{|c|c|c|c|c|c|c|c|c|c|c|c|c|c|c|c|c|c|}
\hline 30 & $\begin{array}{l}\text { Periplaneta } \\
\text { americana }\end{array}$ & Cockroach & Arthropoda & $\mathrm{R}$ & $\mathrm{x}$ & $\mathrm{x}$ & $\mathrm{x}$ & $\mathrm{x}$ & $\mathrm{x}$ & $\mathrm{x}$ & $\mathrm{x}$ & $\mathrm{x}$ & $\mathrm{x}$ & \begin{tabular}{l|l}
$\mathrm{x}$ & 2
\end{tabular} & $\mathrm{x}$ & $\mathrm{x}$ & 12 \\
\hline 31 & $\begin{array}{l}\text { Ploceus } \\
\text { cucullatus }\end{array}$ & $\begin{array}{l}\text { Village } \\
\text { Weaver }\end{array}$ & Ave & $\mathrm{M}$ & $\mathrm{x}$ & $\mathrm{x}$ & $\mathrm{x}$ & & & & & & $\mathrm{x}$ & \begin{tabular}{l|l}
$\mathrm{x}$ & 2
\end{tabular} & $\mathrm{x}$ & $\mathrm{x}$ & 7 \\
\hline 32 & Pica pica & Pied Crow & Ave & $\mathrm{M}$ & $\mathrm{x}$ & $\mathrm{x}$ & $\mathrm{x}$ & $\mathrm{x}$ & $\mathrm{x}$ & $\mathrm{x}$ & $\mathrm{x}$ & $\mathrm{x}$ & $\mathrm{x}$ & \begin{tabular}{l|l}
$\mathrm{X}$ & $\mathrm{2}$ \\
$\mathrm{y}$
\end{tabular} & \begin{tabular}{l|l}
$\mathrm{x}$ & \\
\end{tabular} & $\mathrm{x}$ & 12 \\
\hline 33 & Quela quela & $\begin{array}{l}\text { Common } \\
\text { Weave }\end{array}$ & Ave & $\mathrm{W}$ & $\mathrm{x}$ & $\mathrm{x}$ & $\mathrm{x}$ & & & & & & $\mathrm{x}$ & \begin{tabular}{l|l}
$\mathrm{x}$ & 2
\end{tabular} & $\mathrm{x}$ & $\mathrm{x}$ & 7 \\
\hline 34 & Ratus ratus & Rat & Mammal & $\mathrm{M}$ & $\mathrm{x}$ & $\mathrm{x}$ & $\mathrm{x}$ & $\mathrm{x}$ & $\mathrm{x}$ & $\mathrm{x}$ & $\mathrm{x}$ & $\mathrm{x}$ & $\mathrm{x}$ & \begin{tabular}{l|l}
$\mathrm{x}$ & 2 \\
\end{tabular} & $\mathrm{x}$ & $\mathrm{x}$ & 12 \\
\hline 35 & Rana trigrina & Frog & Amphibian & $\mathrm{W}$ & & & & & & $\mathrm{x}$ & $\mathrm{x}$ & $\mathrm{x}$ & $\mathrm{x}$ & $\mathrm{x}$ & & & 5 \\
\hline 36 & $\begin{array}{l}\text { Streptopelia } \\
\text { senegalensis }\end{array}$ & $\begin{array}{l}\text { Laughing } \\
\text { Dove }\end{array}$ & Ave & $\mathrm{M}$ & $\mathrm{x}$ & $\mathrm{x}$ & $\mathrm{x}$ & $\mathrm{x}$ & $\mathrm{x}$ & & & & & & \begin{tabular}{l|l}
$\mathrm{x}$ & \\
\end{tabular} & $\mathrm{x}$ & 7 \\
\hline 37 & $\begin{array}{l}\text { Sphodromantis } \\
\text { baccetti }\end{array}$ & $\begin{array}{l}\text { Praying } \\
\text { Mantis }\end{array}$ & Arthropoda & $\mathrm{W}$ & & & & & & & & $\mathrm{x}$ & $\mathrm{x}$ & $\mathrm{X}$ & & $\mathrm{x}$ & 4 \\
\hline 38 & $\begin{array}{l}\text { Trigoniulus } \\
\text { corallinus }\end{array}$ & Millipede & Arthropoda & $\mathrm{R}$ & $\mathrm{x}$ & $\mathrm{x}$ & $\mathrm{x}$ & $\mathrm{x}$ & $\mathrm{x}$ & $\mathrm{x}$ & $\mathrm{x}$ & $\mathrm{x}$ & $\mathrm{x}$ & $\mathrm{x}$ & $\mathrm{x}$ & $\mathrm{x}$ & 12 \\
\hline 39 & Tockus nasutus & $\begin{array}{l}\text { Grey } \\
\text { Hornbill }\end{array}$ & Ave & $\mathrm{W}$ & & & & & & $\mathrm{x}$ & $\mathrm{x}$ & $\mathrm{x}$ & $\mathrm{x}$ & $\mathrm{x}$ & & & 5 \\
\hline 40 & Telescopium sp. & Molusca & Apple Snail & $\mathrm{R}$ & & & & & $\mathrm{x}$ & $\mathrm{x}$ & $\mathrm{x}$ & $\mathrm{x}$ & $\mathrm{x}$ & & & & 5 \\
\hline
\end{tabular}

$\mathbf{R}$ - Resident,M - Local migrant,W - WandererSource: Author’s fieldwork, 2016.

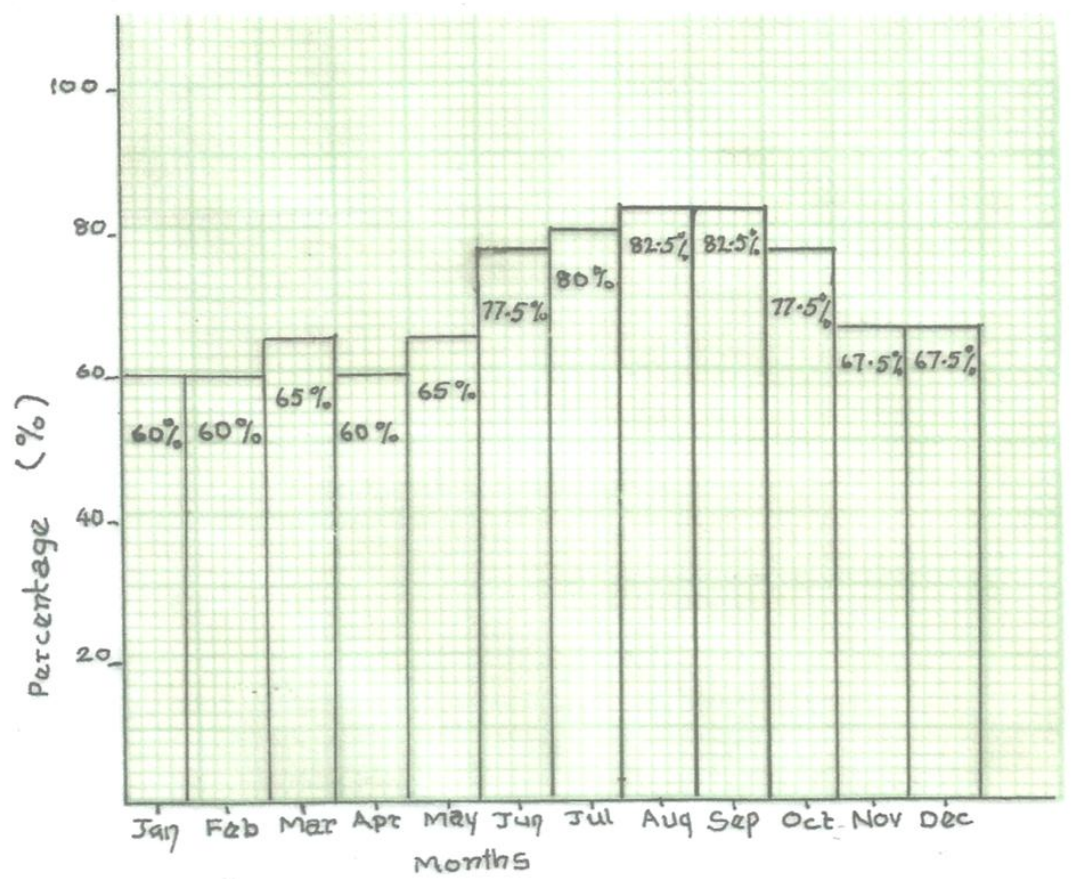

Fig 2: Percentage of monthly observations of animal community in the study area.

The result show that 24 species representing 60 per cent on the list of focal species used in this study in the month of January, February and April (Fig. 2). March and May recorded 26 species each representing 65 per cent; November and December, 27 species each, representing 67.5; and June and October had 31 species each, representing 77.5 per cent per month. July recorded 32 species representing 80 per cent, while August and September had the highest number of species, 33, representing 82 per cent each of the total number of species identified in the study. 


\section{TABLE 2: ANALYSIS OF VARIANCE OF ANIMAL COMMUNITY DISTRIBUTION AT HENSHAW TOWN, ANANTIGHA AND LEMNA DUMPSITES \\ S/N Source \\ 1 Between Samples \\ 2 Within Sample TOTAL Sum of Squares $d$ \\ $22,792,969.40$ \\ $1,423,994.30$ \\ $24,216,963.70$ \\ Variance Estimate \\ $11,396,484.70$ \\ $42 \quad 33,904.62$ \\ $44 \quad 11,430,389.32$ \\ F-ratio \\ 336.13}

The result in TABLE 2 indicates that the F-value, 3.23 is less than the calculated F-value, 336.13, at 0.05 ; hence, the null hypothesis is not accepted. This implies that there is a significant difference of the animal community diversity in the dumpsites in Calabar Metropolis. The faunal species diversity observed in the dumpsites is determined in part by the content rather than geographic extent. The peak of faunal diversity associated with dumpsite is at the Anantigha and Lemna dumpsites. The diversity at Lemna dumpsite is not as great as that located at Henshaw Town dumpsite but is greater than Anantigha dumpsite and diversity decreases southward toward the center of the Metropolis. The diversity at Lemna dumpsite is uniform and relatively high. Even though the dumpsites are isolated from one another, most of the species have broad distribution and endemism seems to be low. This further confirmed that human already had profound effect on dumpsite biodiversity. In addition, Table1 shows the pre-eminent position of certain animals with clear-cut distribution throughout the year. These animals include Canis familiaris (Dog), Felis catus (Cat), Ratus ratus (Rat) and Galus galus domesticus (Domestic Hen) identified as local migrants. The presence of these migrants throughout the year at the dumpsites could have dire consequences in the propagation and spread of infectious diseases. Animals such as dogs and cats are pets, forage the dumpsites and move back home. Similarly flies cockroaches and rodents though resident, often times find way to human residence. These animals are indeed veritable vehicles for the transmission of infectious diseases from dumpsites to the hosts. Viruses, bacteria, fungi and other parasites can invade the body of animals found at dumpsites. For instance, worms (hookworms and tapeworms) and insects that burrow under skin and are carried to the human community. These vehicles sustain the disease organisms' transmission between the dumpsites and hosts. Pathogens at the dumpsite through run-off and peculation contaminate water and food resulting in such diseases as infectious hepatitis and typhoid fever.

\section{CONCLUSION}

The effects of animal composition in this study suggest the importance for understanding the management of city dumpsites. There is little information about the reality of interacting assemblages of fauna in city dumpsites. There is less information about the suitability of such assemblages; investigation should provide information about the likely composition of derived animals in artificial ecosystems. Everyone has a dumpsite address; by either the distance or use, in some cases, both distance, and uses. The people living in most of these addresses have radically altered the volume and content of the dumpsite around. The rapidly changing condition of dumpsites poses threat to human health in the study area. The three health impact spheres (FIG 1) determined through Participatory Appraisal (PA) indicate that the Anantigha and Henshaw Town dumpsites are expanding in volume and areal extent. Keeping dumpsites in the residential domain facilitates environmental health hazards; in this case, its closeness to Calabar River and Creeks of Cross River can facilitate water-borne, water-based and water-related diseases. It can also promote water-scarce disease, a condition where freshwater is scarce and sanitation is poor. In a typical dumpsite ecosystem in Calabar Metropolis, health-threatening vectors are commonplace and this provide conduit for infectious diseases. Vector animals such as Canis familiaris, Musa domestica and Anopheles stephensi responsible in the transmission of diseases to human are integral part of dumpsites. Also in the list are scavengers such as Cathates aura and Pica pica. Rising level of the volume and areal extent of dumpsites will pose serious threat health in such environment.

A major failing of biodiversity management of dumpsites is that little is known from researches in developing and less developed countries. This study has created additional baseline for the record of the diversity of animal composition at city dumpsites. This has further appreciated their role in propagating, proliferating and infecting humans as vectors and should not be taken for granted

\section{REFERENCES}

[1] Pickering, K. T. and Owen, L. A. (1995) An introduction to global environmental issues, London, Butler \& Tanner Ltd.

[2] Oka, P. O., Majuk, S. M. and Eni, D. I. (2016) The unnoticed benefits of city dumpsites in Cross River tate, Nigeria. Indian Journal of Applied Research, Vol 6 (6) 13 - 19.

[3] Haines-Young, R. and Potschin, M. (2009). The link between biodiversity, ecosystem services and human well-being, Centre for Environmental Management. School of Geography, University of Nottingham, Chapter 6, page 1. 
[4] McKee, S. P., Levi, D. M. and Movshon, J. A. (2003). The nature and variety of visual deficit in amblyopia. Journal of vision, 3, 380 - 405.

[5] Cincotta, R. P., Wisnewski, J. and Engelman, R. (2000) Human population in the biodiversity hotspots. Nature 404, 990 - 992.

[6] Oka, P. O. and Majuk, S. M. (2016) Collaborating with nature: The pristine habitats in Ugep, Yakurr Local Government Area, Nigeria. Journal of Geoscience and Environmental Protection, 4, 46 - 52.

[7] Yeragi, L. A. and Mendhulkar, V. D. (2015). Biodiversity around Garbage area in Kannamwar nagar, Vikhroli Suburb, Mumbai. International Journal of Research in Environmental science and Technology 5(2): $43-48$.

[8] Nigeria Population Commission, National Population Census, 2006. Kjellen, M. and McGranahan, G. (1997) Urban water: towards health and sustainability. Stockholm, Stockholm Environmental Institute. 1 -54 .

[9] Bradley, D. (1994) Health, environment and tropical development. In: Cartledge, B., ed. Health and the environment: The Linacre lectures 1992 - 3. Oxford, Oxford University Press, p. 126- 149.

[10] Lambeck, R. J. (1997). Focal species: a multi-species umbrella for nature conservation. Conservation Biology 11, $849-856$. 